\title{
Selva Zoque, Mexico: an important Mesoamerican tropical region for reptile species diversity and conservation
}

\author{
José Luis Aguilar-López', Ricardo Luría-Manzano², \\ Eduardo Pineda', Luis Canseco-Márquez ${ }^{3}$
}

I Red de Biología y Conservación de Vertebrados, Instituto de Ecología A. C., Carretera antigua a Coatepec 351, El Haya, Xalapa, C.P. 91073, Veracruz, México 2 Departamento de Ecologia, Instituto de Biociências, Universidade de São Paulo, Rua do Matão, Travessa 14, Cidade Universitária, 05508-090, São Paulo, São Paulo, Brazil 3 Departamento de Biología Evolutiva, Laboratorio de Herpetologia, Facultad de Ciencias, Universidad Nacional Autónoma de México, A.P. 70-399, C.P. 04510, México City, México

Corresponding author: Ricardo Luría-Manzano (ricardolm@ib.usp.br)

Academic editor: Anthony Herrel | Received 27 April 2021 | Accepted 8 July 2021 | Published 3 August 2021

http://zoobank.org/F1D9569A-E45E-4B64-857F-9832164D0DBO

Citation: Aguilar-López JL, Luría-Manzano R, Pineda E, Canseco-Márquez L (2021) Selva Zoque, Mexico: an important Mesoamerican tropical region for reptile species diversity and conservation. ZooKeys 1054: 127-153. https://doi.org/10.3897/zookeys.1054.67916

\begin{abstract}
The Selva Zoque region is characterized by a great variety of ecosystems for which there is little information about reptile species diversity and their conservation status. This study is the first assessment of the species richness, composition, and conservation status of reptiles of this region. Additionally, this information is compared with that of seven other tropical regions in northern Mesoamerica. In total, 141 native reptile species belonging to 81 genera and 29 families are recorded for the Selva Zoque region. Sixty species ( $42 \%$ of the total) recorded in Selva Zoque are in high-risk categories according to the Mexican Ministry of the Environment, the highest number for the Mexican regions of Mesoamerica. According to the IUCN, six species are in high-risk categories, seven species are in Data Deficient, and $23(16 \%)$ have not been evaluated yet. According to the Environmental Vulnerability Scores approach, 28 species $(20 \%)$ are in the high vulnerability category. The Selva Zoque species composition is most similar to Los Tuxtlas and Lacandona regions, and most dissimilar to Sian Ka' an Biosphere Reserve. The reptilian fauna of Selva Zoque has a distinctive composition, with the highest number (11 species) of endemic reptiles in the northern Mesoamerican, and species from two biogeographic provinces: the Gulf of Mexico and
\end{abstract}

Copyright José Luis Aguilar-López et al. This is an open access article distributed under the terms of the Creative Commons Attribution License (CC BY 4.0), which permits unrestricted use, distribution, and reproduction in any medium, provided the original author and source are credited. 
the Mexican Pacific Coast. These results indicate that the Selva Zoque is the most diverse region in native reptile species in northern Mesoamerica, highlighting it as extremely important for the conservation of the reptile fauna at local (southern Mexico) and regional levels (northern Mesoamerica).

\section{Keywords}

Compositional similarity, conservation value, Data Deficient, reptile fauna, species composition, species richness

\section{Introduction}

The 25 biodiversity hotspots identified by Myers et al. (2000) share two characteristics: each one harbors endemic plant species representing at least $0.5 \%$ of the global total, and have lost $\geq 70 \%$ of their primary vegetation. Of these regions, Mesoamerica ranks fifteenth in relation to the latter characteristic ( $80 \%$ of primary vegetation lost; Myers et al. 2000), and ranks third in deforestation rate among the 13 hotspots for which information is available (Brooks et al. 2002). Despite this scenario, some areas still remain covered by primary vegetation (FAO 2011), highlighting the ongoing conservation value of this region.

One such region is the Selva Zoque, composed by the Uxpanapa-Chimalapas zone (UC) and El Ocote Biosphere Reserve, is located on the Isthmus of Tehuantepec in the states of Veracruz, Oaxaca, and Chiapas in southern Mexico. The Selva Zoque region is the second largest extension of well-conserved tropical forest in northern Mesoamerica, is a Pleistocene refuge with high number of endemic species (Pérez-Farrera et al. 2016), contains a large variety of vegetation types (Peterson et al. 2003) and has a broad range of elevation spanning 100 to $2300 \mathrm{~m}$ a.s.l. Additionally, the Selva Zoque region, together with the protected area La Sepultura Biosphere Reserve, in the state of Chiapas, make up the La Selva Zoque-La Sepultura Priority Conservation Area (Arriaga et al. 2000b). Currently, detailed knowledge of the vertebrate species diversity in the entire Selva Zoque, or a large portion of it, is available only for birds (Peterson et al. 2003), mammals (Lira-Torres et al. 2012), and amphibians (Aguilar-López et al. 2016a). For other groups such as reptiles, our knowledge of species richness, species composition, and conservation status is limited to El Ocote Biosphere Reserve, where the reptile diversity has been revised on several studies (Reynoso et al. 2011; LunaReyes et al. 2017; Muñoz-Alonso et al. 2017) and scarce in UC zone. Herpetological expeditions have been carried out in the UC zone since at least the middle of the last century (Taylor 1951; Duellman 1960; Lynch and Wake 1989) but have focused mainly on amphibians. Moreover, herpetofaunal collection has been limited to few localities, and extensive portions of the region remain with no information.

Worldwide, habitat modification represents the most common threat to terrestrial reptile species, with one in five species included in high-risk categories of extinction (Vulnerable, Endangered, or Critically Endangered) by the IUCN. A further one in five species is listed in the Data Deficient category, and four of ten have not been 
evaluated according to the criteria of the Red List (Uetz et al. 2018; IUCN 2021). In Mexico, it is estimated that 13\% of reptile species are threatened and for another $16 \%$ there is insufficient information (in Data Deficient category) to evaluate its extinction risk level (IUCN 2021). On the other hand, about half of the species are included in the high-risk of extinction categories on the species list compiled by the Mexican Ministry of the Environment (NOM-059-SEMARNAT-2010). Given the variety of tropical forests that cover the Selva Zoque region, along with its geographic location and environmental heterogeneity (Wendt 1987; de Teresa 2000; SEMARNAT 2001), a high reptile diversity may inhabit in this region, with a significant portion of species under high risk of extinction.

Based on a comprehensive review of databases, scientific literature, and fieldwork, we provide the first assessment of species richness, species composition and distribution, and conservation status of the reptile fauna inhabiting the Selva Zoque region. Additionally, we compared this information with other tropical regions on the northern end of Mesoamerica.

\section{Materials and methods}

\section{Study site}

The Selva Zoque region is located in southern Mexico east of the Isthmus of Tehuantepec (Fig. 1). Mountains and hills dominate the region (Wendt 1987; SEMARNAT 2001; Ortiz-Pérez et al. 2004). The region is covered by several vegetation types, the main ones are evergreen tropical forest (100-1000 m a.s.l.), semi-evergreen tropical forest (600-1200 m a.s.l.), deciduous tropical forest (100-600 m a.s.l.), tropical montane cloud forest (1100-1800 m a.s.l.) and pine-oak forest (1800-2300 m a.s.l.) (Wendt 1987; SEMARNAT 2001). Mean annual temperature ranges from 12 to $23^{\circ} \mathrm{C}$ and mean annual rainfall ranges from 800 to $4400 \mathrm{~mm}$ (Vidal-Zepeda 1990; SEMARNAT 2001). We delimited the study area using the polygon set by Arriaga et al. (2000a) for the Selva Zoque-La Sepultura Priority Conservation Area but excluded La Sepultura Biosphere Reserve (Fig. 1).

\section{Data collection}

We consulted two databases between January 2017 and May 2021: the National Information System on Biodiversity (SNIB) curated by the National Commission for the Knowledge and Use of Biodiversity (CONABIO) and the Global Biodiversity Information Facility (GBIF; www.gbif.org). We also reviewed the scientific literature on reptiles from the study region (Navarro-Singüenza and Meave-Castillo 1998; Espinoza et al. 1999; Reynoso et al. 2011; Carmona-Torres 2013; Aguilar-López et al. 2014; Canseco-Márquez and Ramírez-González 2015; Scarpetta et al. 2015; Aguilar-López et al. 2016b; Gray et al. 2016; Luna-Reyes et al. 2017; Muńoz-Alonso et al. 2017; 


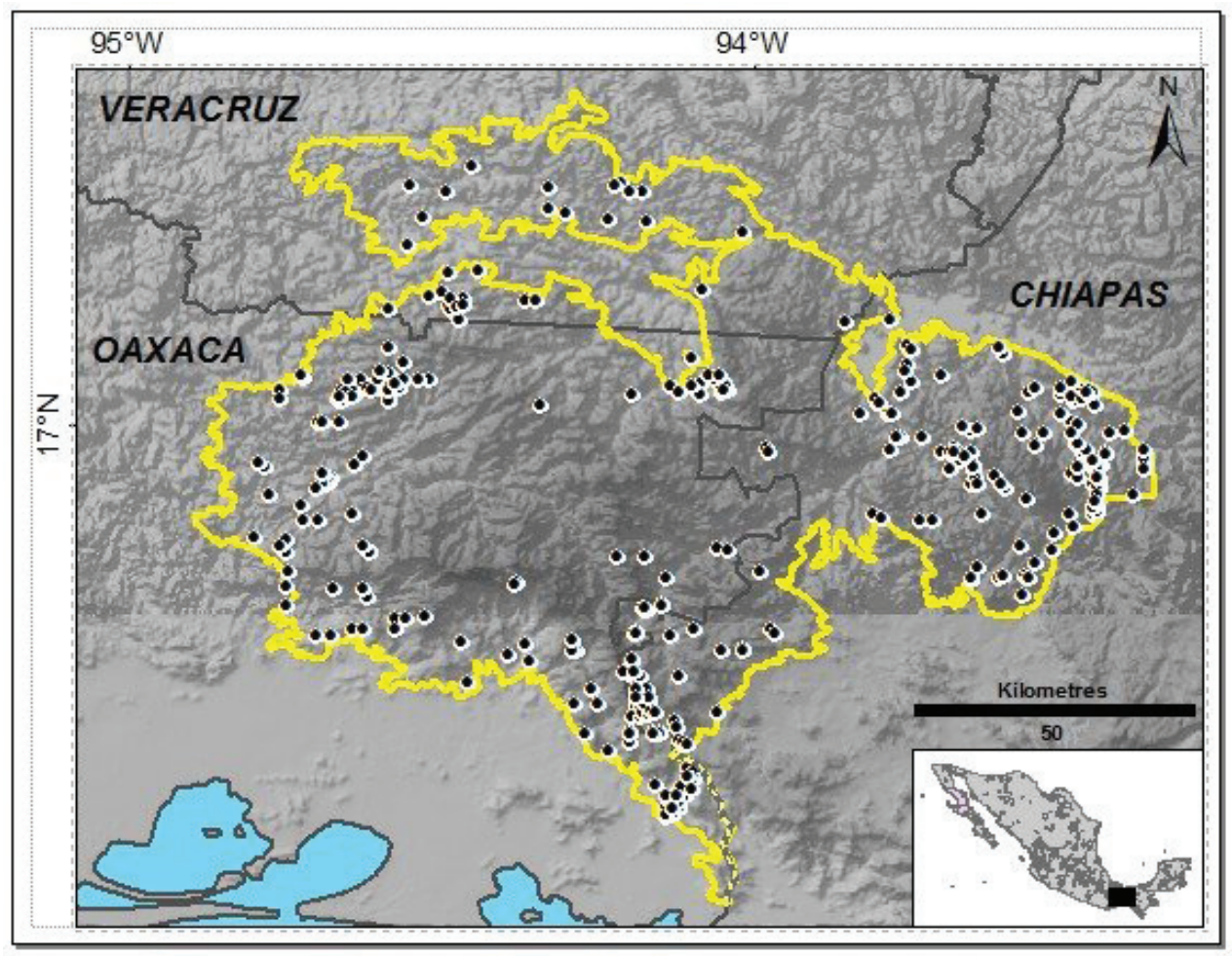

Figure I. Location of the Selva Zoque region. The yellow line denotes our study area limits, the thin black line indicates state boundaries, and black circles denote localities in which reptiles have been recorded.

Campbell et al. 2018; del Moral-Flores et al. 2019). Additionally, we conducted fieldwork during 2013 and 2014 in surroundings of Arroyo Zarco, Uxpanapa, in Veracruz $\left(17^{\circ} 11^{\prime} \mathrm{N}, 94^{\circ} 28^{\prime} \mathrm{W}\right)$, and San Francisco La Paz $\left(17^{\circ} 5^{\prime} \mathrm{N}, 94^{\circ} 8^{\prime} \mathrm{W}\right)$, La Fortaleza $\left(17^{\circ} 9^{\prime} \mathrm{N}, 94^{\circ} 13^{\prime} \mathrm{W}\right)$, and La Esmeralda $\left(17^{\circ} 9^{\prime} \mathrm{N}, 94^{\circ} 46^{\prime} \mathrm{W}\right)$, in Santa María Chimalapa, Oaxaca. We surveyed areas with evergreen tropical forest and semi-evergreen tropical forest using standard visual encounter survey techniques (Crump and Scott 1994) during the day and at night. Cumulative sampling effort was 3250 person-hours.

We cross-checked records obtained from the three sources of information to avoid duplication, since the databases consulted might have records of the same specimens. Only records with precise geographic coordinates or detailed information about the collection and observation site were included, and from these records we compiled a general database.

To compare the data we compiled for the Selva Zoque region with the data from seven other tropical regions, we obtained information about reptile species richness and species composition from: 1) Los Tuxtlas in Veracruz (López-Luna 2017), 2) Las Choapas municipality in Veracruz (Aguilar-López and Canseco-Márquez 2006), 3) La Sepultura Biosphere Reserve in Chiapas (Nuñez-Orantes and Muñoz-Alonso 2000; Reynoso et al. 2011; Clause et al. 2020a, b), 4) the Lacandona rainforest in Chiapas (Hernández-Ordóńez et al. 2015), 5) the Calakmul Biosphere Reserve in Campeche 
(Calderón-Mandujano et al. 2010; Colston et al. 2015), 6) the Sian Ka'an Biosphere Reserve in Quintana Roo (Calderón-Mandujano et al. 2008), and 7) the Mayan Forest in Guatemala (Lee 1996; Campbell 1998).

\section{Data processing and analysis}

To identify the spatial distribution of reptile records in the study region, we projected all geo-referenced records onto our study area polygon using ArcGIS software, version 10.0 (ESRI 2010). To determine the distribution and taxonomically standardize the data set of species that inhabit the Selva Zoque and the other tropical regions, we consulted the specialized literature documenting taxonomic changes and descriptions of new species (Wüster et al. 2005; Castoe et al. 2009; Köhler 2010; Linkem et al. 2011; Cadle and Savage 2012; Hedges and Conn 2012; Iverson et al. 2013; Porras et al. 2013; Köhler et al. 2014; Ruane et al. 2014; Blair et al. 2015; Meza-Lázaro and Nieto-Montes de Oca 2015; Card et al. 2016; Gray et al. 2016; Köhler et al. 2016; McCranie and Hedges 2016; Wallach 2016; Nieto-Montes de Oca et al. 2017; Campbell et al. 2018; Carbajal-Márquez et al. 2020; Jadin et al. 2020; McCranie et al. 2020; Reyes-Velasco et al. 2020; Ramírez-Reyes et al. 2021). Using the compiled data, we defined four distribution categories: species distributed outside Mesoamerica as widely distributed species (WD), species restricted to Mesoamerica (MA), species restricted to northern Mesoamerica (MAMx), and species restricted to one of the eight regions considered. We delimited Mesoamerica as suggested by Campbell (1999) and considered northern Mesoamerica as the zone corresponding to Mexico. To determine the extinction risk category for each species, we consulted the list of Species at Risk published by SEMARNAT, updated in 2018 (NOM-059-SEMARNAT-2010), the Red List maintained by the International Union for the Conservation of Nature (IUCN 2021), and the Environmental Vulnerability Score (EVS) proposed by Wilson et al. (2013). SEMARNAT's categories are: Subject to Special Protection (Pr), Threatened (A), and Endangered (P). The IUCN's three high-risk categories are: Vulnerable (VU), Endangered (EN) and Critically Endangered (CR); its low-risk categories are: Least Concern (LC) and Near Threatened (NT). We also included species in the Data Deficient (DD) category, and those Not evaluated (NE) by the IUCN. In addition, we consulted the EVS of Mexican reptile species that have been evaluated and assigned to one of three categories of vulnerability to environmental degradation: low (3-9), medium (10-13) and high (14-19). For the Mayan Forest in Guatemala, we were only able to assign the IUCN categories since the area lies outside of SEMARNAT's jurisdiction and there is not an evaluation of EVS for reptiles of Guatemala.

We compared reptilian faunal composition between regions using Jaccard's similarity index (Magurran 2004), which uses presence-absence data and is expressed as:

$$
C_{j}=\frac{a}{a+b+c}
$$


where $a=$ the number of species shared between the two sites under comparison, $b=$ number of species exclusive to the first site, and $c=$ number of species exclusive to the second site. The index ranges from zero to one, with zero indicating that no species are shared between the sites being compared, and one indicating that all species are found in both sites. We plotted a dendrogram using PAST software version 2.17c (Hammer et al. 2001) to represent the relationship between sites in terms of their similarity in species composition according to the Jaccard index. For this analysis, we only included native species.

\section{Results}

\section{Species richness, distribution, and conservation status}

A total of 141 native reptile species belonging to 81 genera and 29 families has been recorded at the Selva Zoque region. These comprise 62 species of lizards, 70 snakes, seven turtles, and two crocodilians (Appendix 1). The best represented families are Dipsadidae and Colubridae, with 29 and 25 species, respectively, followed by Dactyloidae with 18 species, Phrynosomatidae with nine species, and Viperidae with seven species. The families with the fewest species in the region are Eublepharidae, Helodermatidae, Mabuyidae, Phyllodactylidae, Scincidae, Boidae, Natricidae, Sybinophiidae, Leptotyphlopidae, Loxocemidae, Dermatemydidae, Emydidae, and Geoemydidae, with one species each one. Three non-native species have been recorded in the region, the lizards Anolis sagrei Duméril \& Bibron Gehyra mutilata (Wiegmann) and Hemidactylus frenatus Duméril and Bibron. During our fieldwork (2013-2014), we recorded 48 species (Appendix 1), although all of them had been previously recorded.

Reptiles have been recorded mostly on the periphery of the study region, notably on western, southern and eastern end portions. In the northwest, northeast, and west, reptile collections are located below $1000 \mathrm{~m}$ a.s.l., while in the southeast, most of collections are between 1000 and $2000 \mathrm{~m}$ a.s.l. The central portion of Chimalapas, the mountainous zone known as Espinazo del Diablo in Uxpanapa and a zone between El Ocote Biosphere Reserve and UC zones corresponding to the northwest extreme of Cintalapa in Chiapas, remain with no collection of reptiles (Fig. 1). The distribution of eleven of the 141 native species (8\%) is restricted to the Selva Zoque region, 26 species $(18 \%)$ are distributed in the northern part of Mesoamerica that corresponds to Mexico, 66 species (47\%) are distributed on Mesoamerica, and 38 species (27\%) have a wide distribution, extending beyond Mesoamerica (Appendix 1).

Of the reptile species recorded in the Selva Zoque region, 60 species (42\%) are in high-risk categories according to SEMARNAT: 39 species in the Subject to Special Protection category (Pr), 18 species are in the Threatened category (A) and three are Endangered (P). According to the IUCN Red List, six species (4\%) are included in high-risk categories: three are Vulnerable (VU), two are Endangered (EN), and one is Critically Endangered (CR). Additionally, seven species are in the Data Deficient cat- 
egory (DD) and 23 species have not been evaluated (NE). The remaining 105 species are in low-risk categories. According to the EVS system, 28 species $(20 \%)$ are in the high vulnerability category (Appendix 1).

\section{Comparison of the richness, composition, and conservation status of the rep- tile species from the Selva Zoque region with that of other tropical regions}

With 141 native species recorded, the Selva Zoque region harbors the highest reptile species richness among the tropical regions considered in this study, surpassing Los Tuxtlas (113 species). The Mayan Forest ranks third (107 species), followed by La Lacandona (89 species), La Sepultura (79 species), Calakmul (73 species), Sian Ka'an (63 species), and finally Las Choapas (56 species; Table 1). The Los Tuxtlas Biosphere Reserve, with four species, has the highest diversity of non-native species, followed by Selva Zoque and Calakmul with three. La Sepultura, Sian Ka'an, and Las Choapas have two non-native species, and the Mayan Forest and Lacandona each have only one.

The dendrogram indicates that La Sepultura has the most dissimilar species composition of the nine regions (Fig. 2). This Biosphere Reserve is followed by Selva Zoque, Las Choapas and Los Tuxtlas in terms of their dissimilarity in relation to the remaining regions. The four remaining regions in turn form a group with a value of Jaccard index $\left[C_{j}\right]=0.5$ (Fig. 2). The composition analysis by pairs indicates that Los Tuxtlas had the species composition most similar to that of Selva Zoque, with $44 \%$ shared species $\left(C_{j}=0.44\right)$, followed by Lacandona $\left(C_{j}=0.39\right)$, whereas the region with the least similar species composition to Selva Zoque was Sian Ka' an $\left(C_{j}=0.20\right)$. The regions with the most similar species composition were Lacandona and Mayan Forest in Guatemala $\left(C_{j}=0.72\right)$, followed by Sian Ka' an and Calakmul $\left(C_{j}=0.58\right)$. The least similar regions were Sian $\mathrm{Ka}^{\prime}$ an and La Sepultura $\left(C_{j}=0.14\right)$.

The Selva Zoque and Los Tuxtlas regions have the highest number of endemic species to the regions, with eleven each, followed by La Sepultura (three species) and Mayan Forest with one endemic species while the rest of regions do not have endemic species (Appendix 1). Also, the Selva Zoque region has the highest number of species in high-risk categories of extinction according to the NOM-059 criteria, with 60 spe-

Table I. Taxonomic composition of native reptile species recorded in the Selva Zoque region and seven other regions in northern Mesoamerica. Non-native species are not included in the taxonomic composition data.

\begin{tabular}{lccccccccc}
\hline Tropical region & Orders & Families & Genera & Lizards & Snakes & Turtles & Crocodilians & Native species & Non-native species \\
\hline Selva Zoque & 3 & 29 & 81 & 62 & 70 & 7 & 2 & 141 & 3 \\
Los Tuxtlas & 3 & 29 & 75 & 35 & 63 & 14 & 1 & 113 & 4 \\
Mayan Forest & 3 & 26 & 70 & 35 & 61 & 9 & 2 & 107 & 1 \\
Lacandona & 3 & 25 & 64 & 28 & 52 & 7 & 2 & 89 & 1 \\
La Sepultura & 2 & 25 & 59 & 29 & 47 & 3 & 0 & 79 & 2 \\
Calakmul & 3 & 21 & 51 & 24 & 39 & 9 & 1 & 73 & 3 \\
Sian Ka'an & 3 & 23 & 51 & 25 & 26 & 10 & 2 & 63 & 2 \\
Las Choapas & 3 & 20 & 41 & 20 & 28 & 7 & 1 & 56 & 2 \\
\hline
\end{tabular}



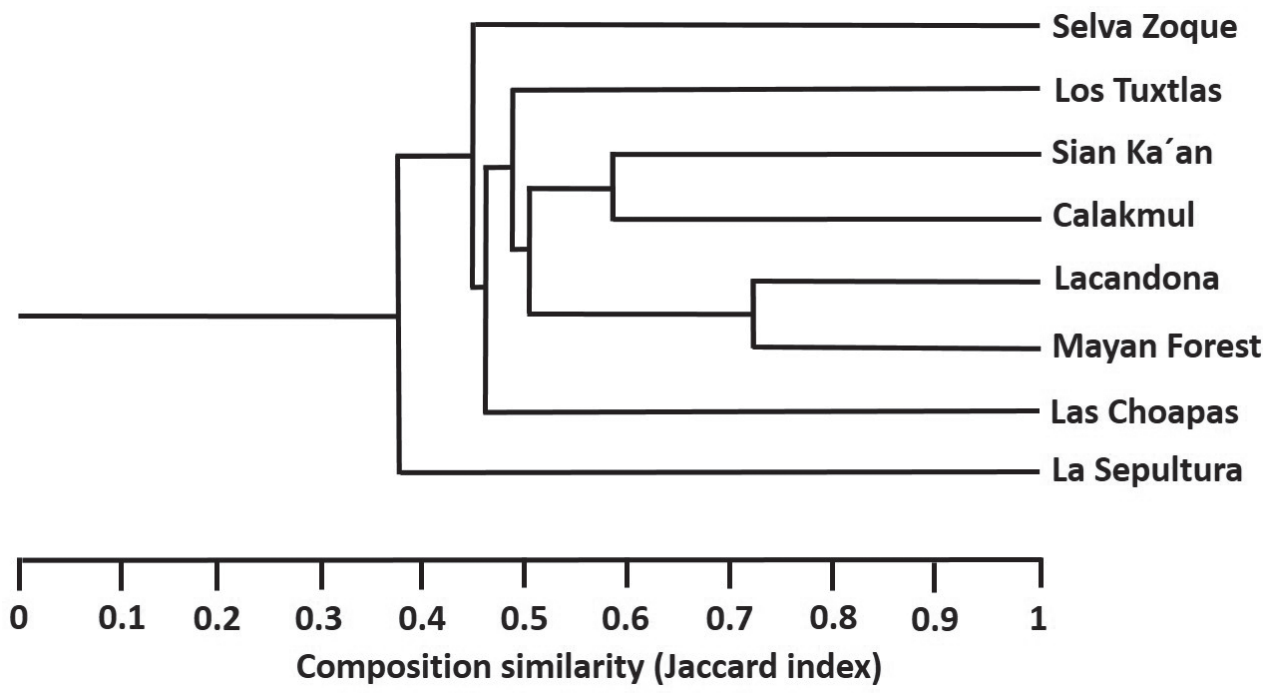

Figure 2. Similarity in reptile species composition for eight tropical areas in northern Mesoamerica.

cies, followed by Los Tuxtlas with 46 species. The other regions have from 33 species (La Sepultura) to 25 species (Las Choapas) in high-risk categories (Fig. 3A). Based on the IUCN Red List, the number of reptiles in high-risk categories of extinction is highest in Los Tuxtlas, with ten species, and the other regions have from one to six species in these categories. The Selva Zoque region has the highest number of species classified as Not evaluated (NE) and with Data Deficient (DD) on the IUCN Red List with 30 species, followed by Los Tuxtlas (24 species); the remaining regions have from eight to $14 \mathrm{NE}$ and DD species (Appendix 1; Fig. 3B). The Selva Zoque has the highest number of species (28) included in the high vulnerability category to environmental degradation, followed by Los Tuxtlas with 18 species; the remaining regions have between five and ten species (Fig. 3C).

\section{Discussion}

Our results show that the Selva Zoque region harbors the greatest reptile species richness in northern Mesoamerica, with a distinctive species composition and several species inhabit exclusively on Selva Zoque region. Furthermore, one in every two reptile species that inhabit in Selva Zoque is threatened, is highly vulnerable or there is not sufficient information to know its extinction risk level. All this underscore the importance of the Selva Zoque region for reptile conservation in Mexico and Mesoamerica. This region also offers opportunities to study unexplored well-preserved tropical forest areas, as well as species for which little is known about their biology, ecology, and conservation status.

The Selva Zoque region is more diverse in native reptile species than even Los Tuxtlas, which has 28 fewer native species (López-Luna 2017). In the Selva Zoque region three exotic species (Anolis sagrei, Gehyra mutilata, Hemidactylus frenatus) have 


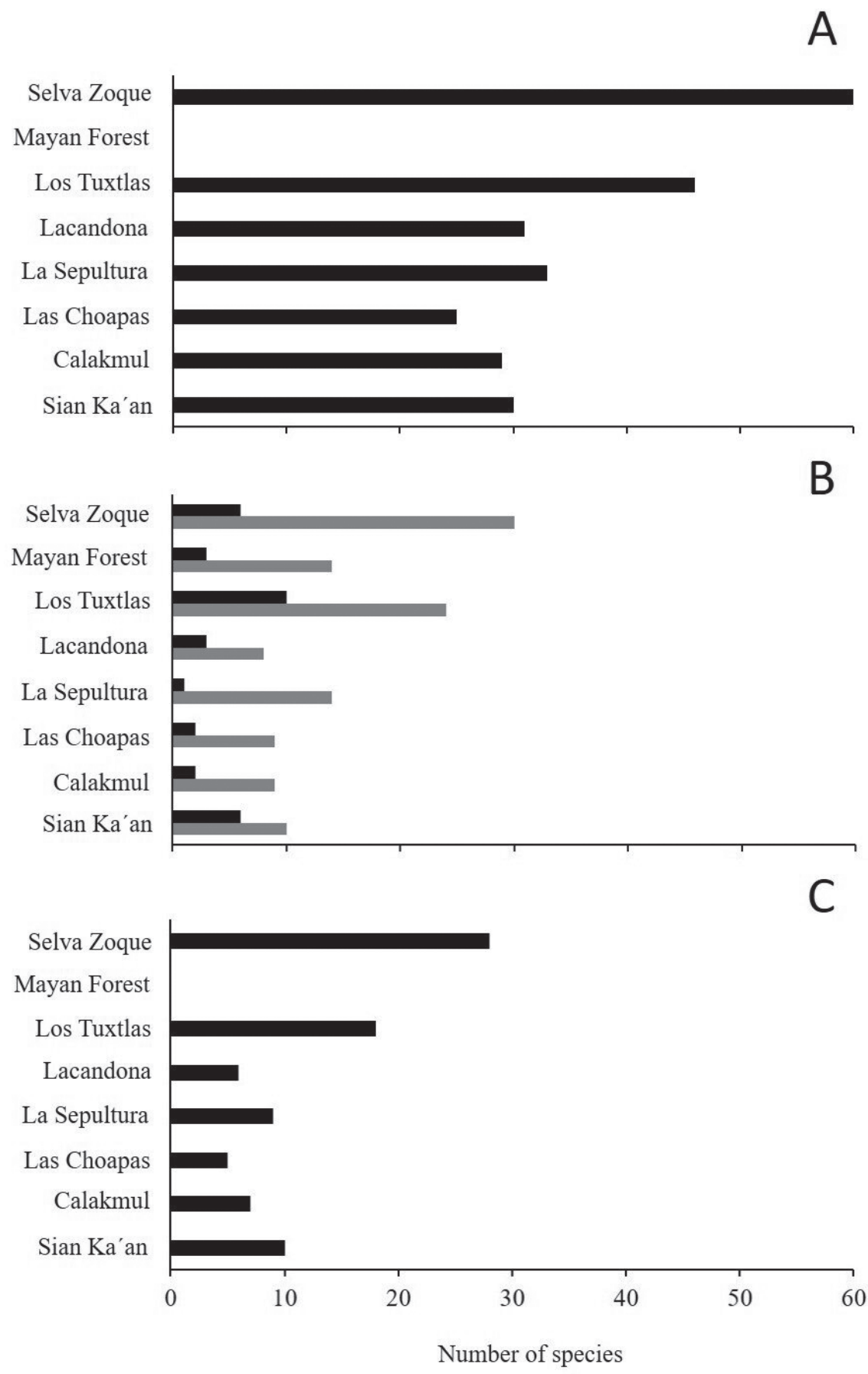

Figure 3. Number of reptile species in high extinction-risk categories according to A NOM-059-SEMARNAT-2010 B IUCN Red List, and C the Environmental Vulnerability Score, for eight tropical regions in northern Mesoamerica. The black bars in the three plots represent the number of species in high extinction-risk categories, and the grey bars in the graph B represent the number of species not evaluated or in the Data Deficient category by the IUCN. 
been recorded, fewer than other regions such as Los Tuxtlas, which is located near the coast. The occurrence of the highest diversity of native species in some portions of Selva Zoque over that of other tropical regions has been previously observed in amphibians (Aguilar-López et al. 2016a). The 141 native reptile species recorded in the Selva Zoque region represent $16 \%$ of the 864 reptile species recorded in Mexico (Flores-Villela and García-Vázquez 2014), 52\% of the 270 reptile species recorded in south-eastern Mexico (Johnson et al. 2010), and 11\% of the 1284 species recorded in Mesoamerica (Johnson et al. 2018).

That said, the inventory of reptile species in the Selva Zoque region is far from complete, particularly in UC zones. In the last three years alone, three new species have been described (Anolis purpuronectes [Gray et al. 2016], Chersodromus australis [Canseco-Márquez et al. 2018] and Cenaspis aenigma [Campbell et al. 2018]), and more species await formal description. Furthermore, several zones within our study area lack reptile records entirely and remain unexplored, and hence additional surveys could reveal reptile species unrecorded for the region and perhaps altogether new species to science. As such, the species richness we report here is likely an underestimate, highlighting the need for additional sampling effort to complete the species inventory of the Selva Zoque region.

The high species richness in the Selva Zoque region may be the result of a series of factors. One is the notably complex orography with lowland zones, both on the Gulf of Mexico and on the Pacific versant, and also a series of mountain ranges of intermediate elevation-the Sierra Atravesada, the Espinazo del Diablo, the Sierra Tres Picos, and Cerro La Colmena (Wendt 1987; Ortíz-Pérez et al. 2004; SEMARNAT 2001)-with elevations from 100 to $2300 \mathrm{~m}$ a.s.l. There is a range of $11^{\circ} \mathrm{C}$ in mean annual temperature across this elevation gradient, and a difference of $3600 \mathrm{~mm}$ in mean annual rainfall across the Selva Zoque (Beard 1955; SEMARNAT 2001). In addition, at least seven vegetation types exist in the region (Arriaga et al. 2000b; SEMARNAT 2001). Together, these factors create a wide variety of habitats for a large diversity of reptile species with different eco-physiological requirements and evolutionary histories.

Although the Selva Zoque did not result clustered with any of the regions in the similarity analysis, Los Tuxtlas and Lacandona Biosphere Reserves are the most similar tropical regions to the Selva Zoque. This pattern has been observed for amphibians in a comparison between Uxpanapa-Chimalapas zone and the same tropical regions (except from La Sepultura) used in this study, and can be explained by the high number of recorded species in these three sites and the high number of species that they share. The Selva Zoque reptile fauna has a combined component of species from two different biogeographic provinces (Morrone 2005): species found in the province of Gulf of Mexico (e.g., Anolis sericeus Hallowell, Holcosus amphigrammus (Smith and Laufe), and those in the province of Mexican Pacific Coast (e.g., Loxocemus bicolor Cope, Porthidium dunni (Hartweg and Oliver), Rhinoclemmys rubida (Cope)). The high percentage $(8 \%)$ of endemism of reptile species to the Selva Zoque region may be due to its stable Pleistocene climate conditions, which allowed for the diversification of different biological groups (Lira-Torres et al. 2012; Rodríguez-Gómez et al. 2013). A pattern 
of high endemicity of the whole Selva Zoque region has been observed for mammals (Escalante 2003), but also in parts of Selva Zoque region like Uxpanapa-Chimalapas for other vertebrates as amphibians (Aguilar-López et al. 2016) or for Chimalapas zone in the case of birds (Peterson et al. 2003).

Our results suggest that Selva Zoque is a priority conservation area for the reptile fauna of Mexico because a relatively high proportion (43\%) of the species that inhabit there are in high-risk of extinction categories in the NOM-059; equivalent to $33 \%$ of all the Mexican reptile species included in this initiative (SEMARNAT 2010). Additionally, a moderate number of reptile species are in the high vulnerability category of environmental degradation (20\%). In contrast, Selva Zoque does not harbor a high number of species in high-risk categories of extinction according to the IUCN. The differences in the number of species in high risk of extinction among initiatives is presumably because the NOM-059 does not consider the entire distribution of the species, it only takes into account the distribution of the species within the Mexican territory, which may lead to a restricted distribution, but only within Mexico, this does not necessarily reflect the entire distribution of the species. Additionally, populations of some reptile species that occur within Mexico may be scarce or may be declining, while populations of those species but outside of Mexico may be stable. Even so, the importance of Selva Zoque region lies in the relatively high proportion (21\%) of species that are classified as Not evaluated (NE) and Data Deficient (DD). Because of the conservation status of vegetation in some areas of the region, it represents an opportunity for gathering information on the biology of these species, and this could contribute to their being assigned a category. This is the case for Abronia bogerti Tihen, Anolis alvarezdeltoroi Nieto Montes de Oca, Xenosaurus arboreus (Lynch and Smith), and Tantilla briggsi Savitsky and Smith (Fig. 4A, B, E, G), endemic species to the Selva Zoque region, or species with distribution in Mesoamerica as Trimorphodon biscutatus (Duméril, Bibron and Duméril), and Epictia phenops (Cope) (Fig. 4H, I). In any case, though widely distributed, some reptile species are considered threatened under three classification systems, such as Anolis pygmaeus Alvarez del Toro \& Smith Bothriechis rowleyi (Bogert), Dermatemys mawii Gray and Crocodylus acutus (Cuvier) (Fig. 4C, J, K, L), all of which have been reported for the other regions (Appendix 1; Fig. 3).

The extensive areas of well-preserved forest in Selva Zoque are mostly located in the Chimalapas zone and El Ocote Biosphere Reserve (Flamenco-Sandoval et al. 2007; Lira-Torres et al. 2012), and offer an opportunity not only for the conservation of reptile diversity, but also for all the biotic diversity that inhabits the Selva Zoque region. Conservation is under the aegis of community initiatives in Chimalapas and has been successful in recent decades (Monterrubio-Solís and Newing 2013); however, it is necessary to implement and subsequently strengthen conservation efforts in areas without any protection. For Uxpanapa and the intermediate zones between Uxpanapa and El Ocote Biosphere Reserve, the constant and accelerated transformation of the original vegetation cover into crops and pastureland (Flamenco-Sandoval et al. 2007; Hernández et al. 2013) underscores the urgent need to stop the advance of the agricultural frontier (Arriaga et al. 2000b). 


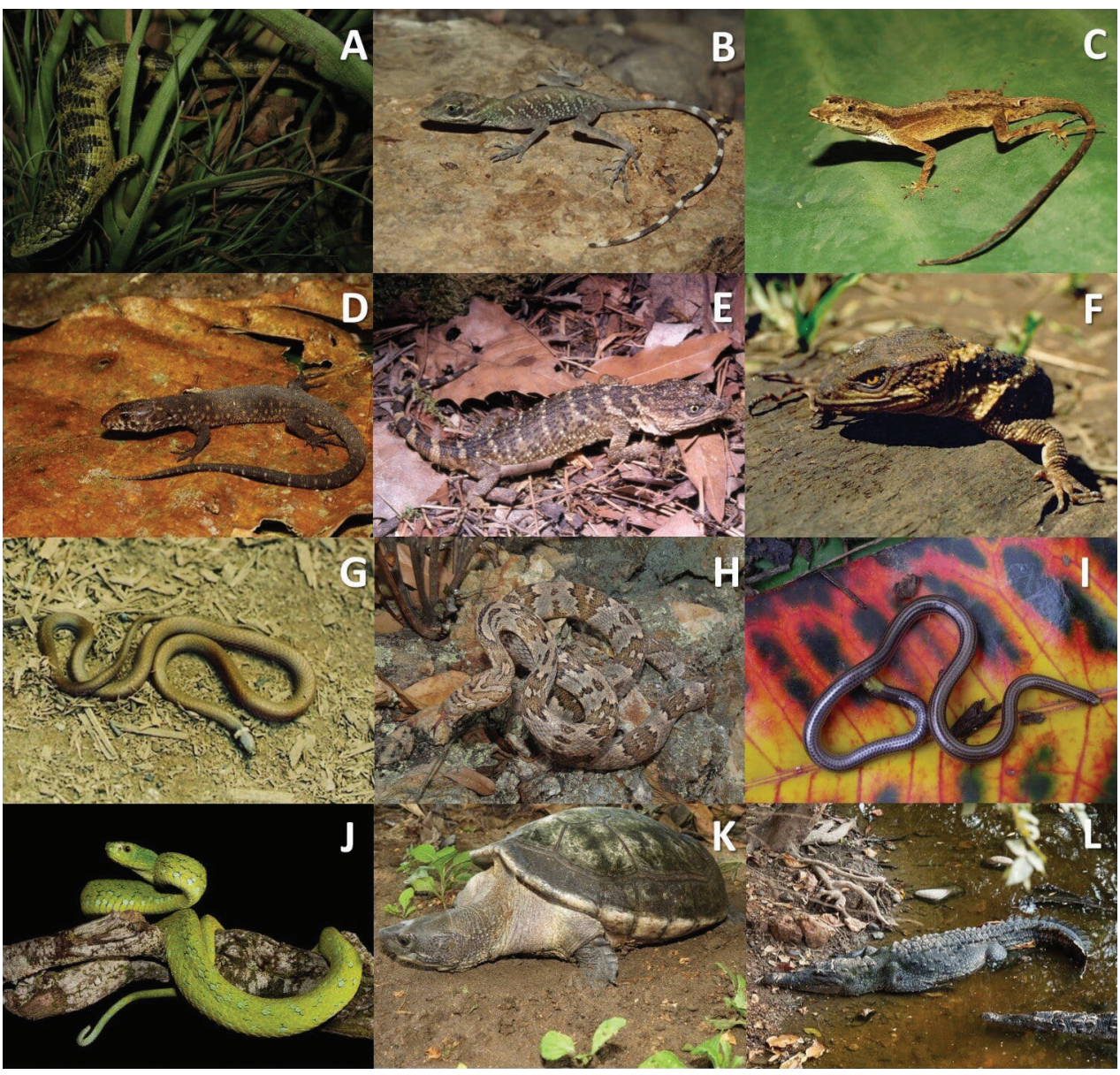

Figure 4. Reptile species in high extinction-risk categories by IUCN, NOM or EVS initiatives, or listed as Data Deficient or Not evaluated by the IUCN red list (see text) A Abronia bogerti B Anolis alvarezdeltoroi $\mathbf{C}$ Anolis pygmaeus $\mathbf{D}$ Lepidophyma tuxtlae $\mathbf{E}$ Xenosaurus arboreus $\mathbf{F}$ Xenosaurus rackhami $\mathbf{G}$ Tantilla briggsi $\mathbf{H}$ Trimorphodon biscutatus $\mathbf{I}$ Epictia phenops $\mathbf{J}$ Bothriechis rowleyi $\mathbf{K}$ Dermatemys mawii and $\mathbf{L}$ Crocodylus acutus.

The implementation of activities proven to be effective in the conservation of reptiles in transformed landscapes in the study region is desirable. These could include: 1) ecological restoration (Smith et al. 2015) to facilitate the recovery of the reptile communities over time, 2) the protection of vegetation remnants (Pulsford et al. 2017) that can harbor important components of overall species diversity, and 3) protection of buffer zones around water bodies (Semlitsch and Bodie 2003) that maintain populations of several species, and also constitute biological corridors (Burbrink et al. 1999). Finally, the protection of Uxpanapa portion of Selva Zoque can contribute to the connection of natural protected areas of different governance types in the western (community protected areas of the Chimalapas, in Oaxaca) and eastern (federal protected area El Ocote, in Chiapas) of Selva Zoque (García-Bañuelos et al. 2019). This idea fits completely with the objective of the Mesoamerican Biological Corridor, an interna- 
tional initiative that aims to maintain biological diversity, decrease habitat fragmentation, improve the connectivity of the landscapes and of the ecosystems in Mesoamerica and to impulse social and economic development (Miller et al. 2001).

\section{Acknowledgements}

The authors thank A. Vinalay, C. Nochebuena, D. Aportela, L. Vázquez, L. Alcaide, J. López, M. Oropeza, R. Flores, J. Pelayo, I. Caviedes, F. Vázquez, C. Hernández, and U. García for helping with the fieldwork. Policarpo Ronzón, L. Feria, and A. Vázquez provided logistical support for the trips to the field. The authors are grateful to M. López-Luna for providing the photograph of Crocodylus acutus, to I. Ahumada for providing the photograph of Bothriechis rowleyi, and to L. Badillo for providing the photograph of Epictia phenops. P. Bañuelos prepared the map and B. Delfosse and A. Clause revised the English of the manuscript. The Toala and Chacha families provided accommodation and were our field guides during our work in Uxpanapa. J. Campbell kindly reviewed an early version of the manuscript and offered helpful suggestions, and Roberto Luna-Reyes made useful suggestions on an advanced version of the manuscript. JLAL was awarded graduate studies scholarship No. 344651 by CONACYT. Permits for this study were issued by the Mexican Wildlife Agency, Dirección General de Vida Silvestre of the Secretaría de Medio Ambiente y Recursos Naturales (collecting permit numbers: SGPA/DGVS/03665/06 and SGPA/DGVS/03444/15). This study was funded by project JF-212-CONABIO.

\section{References}

Aguilar-López JL, Canseco-Márquez L (2006) Herpetofauna del municipio de Las Choapas, Veracruz, México. Boletín de la Sociedad Herpetológica Mexicana 14: 20-37.

Aguilar-López JL, Canseco-Márquez L, Pineda E, Luría-Manzano R (2014) Aporte al conocimiento de la distribución de la culebra de cola corta de Linton, Tantillita lintoni en México. Revista Mexicana de Biodiversidad 96: 1292-1294. https://doi.org/10.7550/rmb.46781 Aguilar-López JL, Luría-Manzano R, Pineda E, Aportela D (2016b) Celestus rozellae. Distribution note. Mesoamerican Herpetology 3: 764-765.

Aguilar-López JL, Pineda E, Luría-Manzano R, Canseco-Marquez L (2016a) Species diversity, distribution and conservation status in a Mesoamerican region: Amphibians of the Uxpanapa-Chimalapas region, Mexico. Tropical Conservation Science 9: 1-16. https:// doi.org/10.1177/1940082916670003

Arriaga L, Espinoza JM, Aguilar C, Martínez E, Gómez L, Loa E [Coordinators] (2000a) Mapa de regiones terrestres prioritarias de México. Escala de trabajo 1:1 000 000. Comisión Nacional para el Conocimiento y Uso de la Biodiversidad, México.

Arriaga L, Espinoza JM, Aguilar C, Martínez E, Gómez L, Loa E [Coordinators] (2000b) Regiones terrestres prioritarias para la conservación. México, Comisión Nacional para el Conocimiento y Uso de la Biodiversidad. 
Beard JS (1955) The classification of tropical American vegetation types. Ecology 36: 89-100. https://doi.org/10.2307/1931434

Blair C, Méndez de la Cruz FR, Law C, Murphy RW (2015) Molecular phylogenetics and species delimitation of leaf-toed geckos (Phyllodactylidae: Phyllodactylus) throughout the Mexican tropical dry forest. Molecular Phylogenetics and Evolution 84: 254-265. https:// doi.org/10.1016/j.ympev.2015.01.003

Brooks TM, Mittermeier RA, Mittermeier CG, Da Fonseca GAB, Rylands AB, Konstant WR, Flick P, Pilgrim J, Olfield S, Magin G, Hilton-Taylor C (2002) Habitat loss and extinction in the hotspot of biodiversity. Conservation Biology 16: 909-923. https://doi. org/10.1046/j.1523-1739.2002.00530.x

Burbrink FT, Phillips CA, Heske EJ (1999) A riparian zone in southern Illinois as a potential dispersal corridor for reptiles and amphibians. Biological Conservation 86: 107-115. https://doi.org/10.1016/S0006-3207(98)00054-8

Cadle JE, Savage JM (2012) Systematics of the Dendrophidion nuchale complex (Serpentes: Colubridae) with the description of a new species from Central America. Zootaxa 3513: 1-50. https://doi.org/10.11646/zootaxa.3513.1.1

Calderón-Mandujano RR, Bahena-Basave H, Calmé S (2008) Anfibios y reptiles de la Reserva de la Biósfera de Sian Ka’an y zonas aledañas ( $2^{\text {nd }}$ edn.). COMPACT, ECOSUR, CONABIO, S.H.M, Quintana Roo, 111 pp.

Calderón-Mandujano RR, Pozo de la Tijera C, Cedeño-Vázquez JR (2010) Guía Rústica de los Reptiles de la Región de Calakmul, Campeche, México. ECOSUR, CONABIO, Quintana Roo, 57 pp.

Campbell JA (1984) A new species of Abronia (Sauria: Anguidae) with comments on the herpetogeography of the highlands of southern Mexico. Herpetologica 40: 373-381. https:// www.jstor.org/stable/3892089

Campbell JA (1998) Amphibians and reptiles of Northern Guatemala, the Yucatan, and Belize. Vol. 4, Animal Natural History Series. University of Oklahoma Press, Norman, 400 pp.

Campbell JA (1999) Distribution patterns of amphibians in Middle America. In: Duellman WE (Ed.) Patterns of distribution of amphibians, a global perspective. The Johns Hopkins University Press, Baltimore, 111-210.

Campbell JA, Smith EN, Hall AS (2018) Caudals and calyces: the curious case of a consumed Chiapan colubroid. Journal of Herpetology 52: 459-472. https://doi.org/10.1670/18-042

Canseco-Márquez L, Ramírez-González CG (2015) New herpetofaunal records for the state of Oaxaca, Mexico. Mesoamerican Herpetology 2: 364-367.

Canseco-Márquez L, Ramírez-González CG, Campbell JA (2018) Taxonomic review of the rare Mexican snake genus Chersodromus (Serpentes: Dipsadidae), with the description of two new species. Zootaxa 4399: 151-169. https://doi.org/10.11646/zootaxa.4399.2.1

Carbajal-Márquez RA, Cedeño-Vázquez JR, Martinez-Arce A, Neri-Castro E, MachkourM'Rabet SC (2020) Accessing cryptic diversity in Neotropical rattlesnakes (Serpentes: Viperidae: Crotalus) with the description of two new species. Zootaxa 4729: 451-481. https://doi.org/10.11646/zootaxa.4729.4.1

Card DC, Schield DR, Adams RH, Corbin AB, Perry BW, Andrew AL, Pasquesi GIM, Smith EN, Jezkova T, Boback SM, Booth W, Castoe TA (2016) Phylogeographic and population genetic analyses reveal multiple species of Boa and independent origins of insular dwarf- 
ism. Molecular Phylogenetics and Evolution 102: 104-116. https://doi.org/10.1016/j. ympev.2016.05.034

Carmona-Torres HF (2013) Diversidad herpetofaunística en remanentes de selva alta perennifolia y su relación con áreas conservadas. Ms thesis, National Autonomous University of Mexico, Mexico.

Castoe TA, Daza JM, Smith EN, Sasa MM, Kuch U, Campbell JA, Chippindale PT, Parkinson CL (2009) Comparative phylogeography of pitvipers suggests a consensus of ancient Middle American Highland biogeography. Journal of Biogeography 36: 88-103. https://doi. org/10.1111/j.1365-2699.2008.01991.x

Clause AG, Luna-Reyes R, Nieto-Montes de Oca A (2020a) A new species of Abronia (Squamata: Anguidae) from a Protected Area in Chiapas, Mexico. Herpetologica 76: 330-343. https://doi.org/10.1655/Herpetologica-D-19-00047

Clause AG, Luna-Reyes R, Jimenez-Lang N, Nieto-Montes de Oca A, Martínez-Hernández LA (2020b) Problems with imperfect locality data: distribution and conservation status of an enigmatic pitviper. Amphibian \& Reptile Conservation 14: 185-197.

Colston TJ, Barao-Nóbrega JA, Manders R, Lett A, Willmott J, Cameron G, Hunter S, Radage A, Littlefair E, Williams RJ, López-Cen A, Slater K (2015) Amphibians and reptiles of the Calakmul Biosphere Reserve, México, with new records. Check List 11: 1-7. https://doi. org/10.15560/11.5.1759

Crump ML, Scott Jr NJ (1994) Visual encounter surveys. In: Heyer RW, Donnelly MA, McDiarmid RW, Hayek LC, Foster MS (Eds) Measuring and Monitoring Biological Diversity: Standard Methods for Amphibians. Smithsonian Institution Press, Washington and London, 84-92. de Teresa AP (2000) Los Vaivenes de la Selva: el Proceso de Reconstitución del Territorio Zoque de los Chimalapas. México. Universidad Autónoma Metropolitana, Consejo Nacional de Ciencia y Tecnología y Secretaría de Medio Ambiente, Recurso Naturales y Pesca, México, 180 pp. del Moral-Flores LF, Vázquez-Nuñez LG, Hernández-Arellano T (2019) Primer registro del cocodrilo de pantano Crocodylus moreletii Duméril \& Bibron 1851, en la selva de Los Chimalapas, Oaxaca, México. Revista Latinoamericana de Herpetología 2: 51-54.

Duellman WE (1960) A distributional study of the amphibians of the Isthmus of Tehuantepec, Mexico. University of Kansas publications, Museum of Natural History 13: 19-72.

Escalante-Espinosa T (2003) Determinación de prioridades en las áreas de conservación para los mamíferos terrestres de México, empleando criterios biogeográficos. Anales del Instituto de Biología, Universidad Nacional Autónoma de México, Serie Zoología 74: 211-237.

Espinoza ME, Núñez H, González P, Luna R, Navarrete GD, Cruz E, Guichard C (1999) Lista preliminar de los vertebrados terrestres de la selva "El Ocote", Chiapas. Publicación Especial del Instituto de Historia Natural 2: 1-40.

ESRI (2010) ArcGIS (Version 10.0). Environmental Systems Research Institute, Redlands.

FAO (2011) State of the World's Forests. Food and Agriculture Organization of the United Nations, Rome, 164 pp.

Flamenco-Sandoval A, Martínez-Ramos M, Masera OR (2007) Assessing implications of landuse and land-cover change dynamics for conservation of a highly diverse tropical rain forest. Biological Conservation 138: 131-145. https://doi.org/10.1016/j.biocon.2007.04.022

Flores-Villela O, García-Vázquez UO (2014) Biodiversidad de Reptiles en México. Revista Mexicana de Biodiversidad 85: S467-S475. https://doi.org/10.7550/rmb.43236 
García-Bañuelos P, Rovito SM, Pineda E (2019) Representation of threatened biodiversity in protected areas and identification of complementary areas for their conservation: plethodontid salamanders in Mexico. Tropical Conservation Science 12: 1-15. https://doi. org/10.1177/1940082919834156

Gray L, Meza-Lázaro R, Poe S, Nieto Montes de Oca A (2016) A new species of semiaquatic Anolis (Squamata: Dactyloidae) from Oaxaca and Veracruz, Mexico. Herpetological Journal 26: 253-262.

Hammer O, Harper DAT, Ryan PD (2001) Past: Paleontological Statistics software package for education and data analysis. Paleontologica Electronica 4: 1-9.

Hedges SB, Conn CE (2012) A new skink fauna from Caribbean islands (Squamata, Mabuyidae, Mabuyinae). Zootaxa 3288: 1-244. https://doi.org/10.11646/zootaxa.3288.1.1

Hérnandez IU, Ellis EA, Gallo CA (2013) Aplicación de teledetección y sistemas de información geográfica para el análisis de deforestación y deterioro de las selvas tropicales en la región Uxpanapa, Veracruz. GeoFocus 13: 1-24.

Hernández-Ordóñez O, Arroyo-Rodríguez V, González-Hernández A, Russildi G, Luna-Reyes R, Martínez-Ramos M, Reynoso VH (2015) Range extensions of amphibians and reptiles in the southeastern part of the Lacandona rainforest, Mexico. Revista Mexicana de Biodiversidad 86: 457-468. https://doi.org/10.1016/j.rmb.2015.04.005

IUCN [International Union for Conservation of Nature]. (2021) The IUCN Red List of Threatened Species. Version 2021-1. http://www.iucnredlist.org [accessed on June 25, 2021]

Iverson JB, Le M, Ingram C (2013) Molecular phylogenetics of the mud and musk turtle family Kinosternidae. Molecular Phylogenetics and Evolution 69: 929-939. https://doi. org/10.1016/j.ympev.2013.06.011

Jadin RC, Blair C, Orlofske SA, Jowers MJ, Rivas GA, Vitt LJ, Ray JM, Smith EN, Murphy JC (2020) Not withering on the evolutionary vine: systematic revision of the Brown Vine Snake (Reptilia: Squamata: Oxybelis) from its northern distribution. Organisms Diversity \& Evolution 20: 723-746. https://doi.org/10.1007/s13127-020-00461-0

Johnson JD, Mata-Silva V, Ramírez-Bautista A (2010) The herpetofauna of southeastern Mexico: Biogeography and conservation. In: Wilson LD, Townsend JH, Johnson J (Eds) Conservation of Mesoamerican amphibians and reptiles. Eagle Mountain Publishing, Utah, 322-369.

Johnson JD, Wilson LD, Bryson Jr RW, Köhler G, Nicholson K, Schuett GW, Townsend JH (2018) Herpetofaunal List for Mesoamerica. Mesoamerican Herpetology. http://www. mesoamericanherpetology.com/taxonomic-list.html [accessed on March 5, 2018]

Köhler G (2010) A revision of the Central American species related to Anolis pentaprion with the resurrection of $A$. beckeri and the description of a new species (Squamata: Polychrotidae). Zootaxa 2354: 1-18. https://doi.org/10.11646/zootaxa.2354.1.1

Köhler G, Townsend JA, Petersen CB (2016) A taxonomic revision of the Norops tropidonotus complex (Squamata, Dactyloidea), with resurrection of N. spilorhipis (Álvarez del Toro and Smith, 1956) and the description of two new species. Mesoamerican Herpetology 3: 8-41.

Köhler G, Trejo-Pérez RG, Petersen CB, Méndez de la Cruz F (2014) A revision of the Mexican Anolis (Reptilia, Squamata, Dactyloidae) from the Pacific versant west of the Isthmus de Tehuantepec in the states of Oaxaca, Guerrero, and Puebla, with the description of six new species. Zootaxa 3862: 1-210. https://doi.org/10.11646/zootaxa.3862.1.1 
Lee JC (1996) The Amphibians and Reptiles of the Yucatan Peninsula. Cornell University Press, Ithaca, 512 pp.

Linkem CW, Diesmos AC, Brown RF (2011) Molecular systematics of the Philippine forest skinks (Squamata: Scincidae: Sphenomorphus): testing morphological hypotheses of interspecific relationship. Zoological Journal of the Linnean Society 163: 1217-1243. https:// doi.org/10.1111/j.1096-3642.2011.00747.x

Lira-Torres I, Galindo-Leal C, Briones-Salas M (2012) Mamíferos de la Selva Zoque, México: riqueza, uso y conservación. Revista de Biología Tropical 60: 781-797. https://doi. org/10.15517/rbt.v60i2.3999

López-Luna M (2017) Estado actual de la diversidad y poblaciones de los anfibios y reptiles de Los Tuxtlas. In: Reynoso VH, Coates RI, Vázquez-Cruz ML (Eds) Avances y Perspectivas en la Investigación de los Bosques Tropicales y sus Alrededores: la Región de Los Tuxtlas. Instituto de Biología, Universidad Nacional Autónoma de México, Mexico, 347-369.

Luna-Reyes R, Cundapí-Pérez C, Pérez-López PE, López-Villafuerte A, Rodríguez-Reyes MÁ, Luna-Sánchez JA (2017) Riqueza y diversidad de anfibios y reptiles en Nuevo San Juan Chamula y Veinte Casas, Reserva de la Biosfera Selva El Ocote, Chiapas. In: Ruiz-Montoya L, Álvarez-Gordillo G, Ramírez-Marcial N, Cruz-Salazar B (Eds) Vulnerabilidad Social y Biológica Ante el Cambio Climático en la Reserva de la Biosfera Selva El Ocote. El Colegio de la Frontera Sur, Chiapas, 355-393.

Lynch FJ, Wake DB (1989) Two new species of Pseudoeurycea (Amphibia: Caudata) from Oaxaca, Mexico. Contributions in Science, Natural History Museum of Los Angeles County 411: 11-22.

Magurran AE (2004) Measuring Biological Diversity. Blackwell Publishing, Oxford, 256 pp.

McCranie JR, Hedges SB (2016) Molecular phylogeny and taxonomy of the Epictia goudotii species complex (Serpentes: Leptotyphlopidae: Epictinae) in Middle America and northern South America. PeerJ 4: e1551. https://doi.org/10.7717/peerj.1551

McCranie JR, Matthews AJ, Hedges SB (2020) A morphological and molecular revision of lizards of the genus Marisora Hedges \& Conn (Squamata: Mabuyidae) from Central America and Mexico, with descriptions of four new species. Zootaxa 4763: 301-353. https://doi. org/10.11646/zootaxa.4763.3.1

Meza-Lázaro RN, Nieto-Montes de Oca A (2015) Long forsaken species diversity in the Middle American lizard Holcosus undulatus. Zoological Journal of the Linnean Society 175: 189-210. https://doi.org/10.1111/zoj.12264

Miller K, Chang E, Johnson N (2001) Defining Common Ground for the Mesoamerican Biological Corridor. World Resources Institute, Washington, District of Columbia, 45 pp. Monterrubio-Solís C, Newing HS (2013) Challenges in ICCA Governance: The case of El Cordon del Retén in San Miguel Chimalapa, Oaxaca. In: Porter-Bolland L, Ruiz-Mallén I, Camacho-Benavides C, McCandless SR (Eds) Community Action for Conservation Mexican Experiences. Springer, New York, 63-82. https://doi.org/10.1007/978-1-4614-7956-7_5

Morrone JJ (2005) Hacia una síntesis biogeográfica de México. Revista Mexicana de Biodiversidad 76: 207-252. https://doi.org/10.22201/ib.20078706e.2005.002.303

Muñoz-Alonso LA, Nieblas-Camacho J, Chau-Cortez MA, González-Navarro AB, López-Pérez J, Pérez-López J (2017) Diversidad de anfibios y reptiles en la Reserva de la Biosfera Selva El Ocote: su vulnerabilidad ante la fragmentación y el cambio climático. In: Ruiz-Montoya 
L, Álvarez-Gordillo G, Ramírez-Marcial N, Cruz-Salazar B (Eds) Vulnerabilidad social y biológica ante el cambio climático en la Reserva de la Biosfera Selva El Ocote. El Colegio de la Frontera Sur, Chiapas, 395-447.

Myers N, Mittermeier RA, Mittermeier CG, da Fonseca GAB, Kent J (2000) Biodiversity hotspots for conservation priorities. Nature 403: 853-858. https://doi.org/10.1038/35002501

Navarro-Sigüenza AG, Meave del Castillo JA (1998) Inventario de la biodiversidad de vertebrados terrestres de los Chimalapas, Oaxaca. Informe final SNIB-CONABIO, proyecto No. B002. Universidad Nacional Autónoma de México. Facultad de Ciencias. México, D.F.

Nieto-Montes de Oca A, Barley AJ, Meza-Lázaro RN, García-Vázquez UO, Zamora-Abrego JG, Thomson RC, Leaché AD (2017) Phylogenomics and species delimitation in the knob-scaled lizards of the genus Xenosaurus (Squamata: Xenosauridae) using ddRADseq data reveal a substantial underestimation of diversity. Molecular Phylogenetics and Evolution 106: 241-253. https://doi.org/10.1016/j.ympev.2016.09.001

Nuñez-Orantes O, Muñoz-Alonso A (2000) Inventario Herpetofaunístico de la reserva de la biosfera La Sepultura, Chiapas, México. Informe final SNIB-CONABIO, proyecto No. L003. Secretaría de Medio Ambiente Vivienda e Historia Natural. México, D.F.

Ortiz-Pérez MA, Hernández-Santana JR, Figueroa JM (2004) Reconocimiento fisiográfico y geomorfológico. In: García-Mendoza AJ, Ordóńez MJ, Briones-Salas MA (Eds) Biodiversidad de Oaxaca. Instituto de Biología, UNAM, Fondo Oaxaqueño para la Conservación de la Naturaleza, World Wildlife Fund, Mexico, 43-54.

Pérez-Farrera1 MA, Espinosa-Jiménez JA, López A, Gómez-Domínguez H, Gordillo-Ruiz MC (2016) Flora y vegetación de la Selva Zoque de Chiapas. In: Semahn (Ed.) Ecoregión Zoque: Retos y Oportunidades Ante el Cambio Climático. Secretaria de Medio Ambiente e Historia Natural, Chiapas, 52-76.

Peterson AT, Navarro-Sigüenza A, Hernández-Baños BE, Escalona-Segura G, RebónGallardo F, Rodríguez-Ayala E, Figueroa-Esquivel EM, Cabrera-García L (2003) The Chimalapas Region, Oaxaca, Mexico: a high-priority region for bird conservation in Mesoamerica. Bird Conservation International 13: 227-253. https://doi.org/10.1017/ S0959270903003186

Porras LW, Wilson LD, Schuett GW, Relserer RS (2013) A taxonomic reevaluation and conservation assessment of the common cantil, Agkistrodon bilineatus (Squamata: Viperidae): a race against time. Amphibian and Reptile Conservation 7: 48-73.

Pulsford SA, Driscoll DA, Barton PS, Lindenmayer DB (2017) Remnant vegetation, plantings and fences are beneficial for reptiles in agricultural landscapes. Journal of Applied Ecology 54: 1710-1719. https://doi.org/10.1111/1365-2664.12923

Ramírez-Reyes T, Flores-Villela O, Piñero D, Lathrop A, Murphy RW (2021) Genomic assessment of the Phyllodactylus tuberculosus complex (Reptilia: Phyllodactylidae) in America. Zoologica Scripta. https://doi.org/10.1111/zsc.12492

Reyes-Velasco J, Adams RH, Boissinot S, Parkinson CL, Campbell JA, Castoe TA, Smith EN (2020) Genome-wide SNPs clarify lineage diversity confused by coloration in coralsnakes of the Micrurus diastema species complex (Serpentes: Elapidae). Molecular Phylogenetics and Evolution 147: e106770. https://doi.org/10.1016/j.ympev.2020.106770

Reynoso VH, Paredes-León R, González-Hernández A (2011) Anfibios y reptiles del estado de Chiapas con algunos comentarios sobre los reportes y estudios de diversidad herpeto- 
faunística en la región. In: Álvarez F (Ed.) Chiapas: Estudios sobre su diversidad biológica. Universidad Nacional Autónoma de México, Mexico, 459-509.

Rodríguez-Gómez F, Gutiérrez-Rodríguez C, Ornelas JF (2013) Genetic, phenotypic and ecological divergence with gene flow at the Isthmus of Tehuantepec: The case of the azurecrowned hummingbird (Amazilia cyanocephala). Journal of Biogeography 40: 1360-1373. https://doi.org/10.1111/jbi.12093

Ruane S, Bryson Jr RW, Pyron RA, Burbrink FT (2014) Coalescent species delimitation in milksnakes (Genus Lampropeltis) and impacts on phylogenetic comparative analyses. Systematic Biology 63: 231-250. https://doi.org/10.1093/sysbio/syt099

Scarpetta S, Gray L, Nieto Montes de Oca A, Castańeda M, Herrel A, Losos JB, Luna-Reyes R, Jímenez-Lang N, Poe S (2015) Morphology and ecology of the Mexican cave anole Anolis alvarezdeltoroi. Mesoamerican Herpetology 2: 261-270.

SEMARNAT [Secretaría de Medio Ambiente y Recursos Naturales] (2001) Programa de manejo Reserva de la Biosfera Selva El Ocote. SEMARNAT, CONANP, Chiapas, México, 144 pp. SEMARNAT [Secretaría de Medio Ambiente y Recursos Naturales] (2010) Norma Oficial Mexicana NOM-059. Protección ambiental de especies nativas de México de flora y fauna silvestres-Categorías de riesgo y especificaciones para su inclusión, exclusión o cambioLista de especies en riesgo. Proyecto de Modificación. Agosto 2018. México D.F., México. Diario Oficial de la Federación.

Semlitsch RD, Bodie JR (2003) Biological criteria for buffer zones around wetlands and riparian habitats for amphibians and reptiles. Conservation Biology 17: 1219-1228. https:// doi.org/10.1046/j.1523-1739.2003.02177.x

Smith GC, Lewis T, Hogan LD (2015) Fauna community trends during early restoration of alluvial open forest/Woodland ecosystems on former agricultural land. Restoration Ecology 23: 787-799. https://doi.org/10.1111/rec.12269

Taylor EH (1951) A new Veracrucian salamander. The University of Kansas Science Bulletin 34: 189-193.

Uetz P, Freed P, Hošek J (2018) The Reptile Database. http://www.reptile-database.org [accessed on July 28, 2018]

Vidal-Zepeda R (1990) Mapa de precipitación media anual, escala 1: 4000000. En Precipitación. Tomo II, Sección IV, 4.6. Atlas Nacional de México (1990-1992). Instituto de Geografía, UNAM, Mexico.

Wallach V (2016) Morphological review and taxonomic status of the Epictia phenops species group of Mesoamerica, with description of six new species and discussion of South American Epictia albifrons, E. goudotii, and E. tenella (Serpentes: Leptotyphlopidae: Epictinae). Mesoamerican Herpetology 3: 215-374.

Wendt T (1987) Las selvas de Uxpanapa, Veracruz-Oaxaca, México: Evidencia de refugios florísticos cenozoicos. Anales del Instituto de Biología, Serie Botánica 58: 29-54.

Wilson LD, Mata-Silva V, Johnson JD (2013) A conservation reassessment of the reptiles of Mexico based on the EVS measure. Amphibian and Reptile Conservation 7: 1-47.

Wüster W, Ferguson JE, Quijada-Mascareñas JA, Pook CE, Graca-Salomao M, Thorpe RS (2005) Tracing an invasion: landbridges, refugia, and the phylogeography of the Neotropical rattlesnake (Serpentes: Viperidae: Crotalus durissus). Molecular Ecology 14: 10951108. https://doi.org/10.1111/j.1365-294X.2005.02471.x 


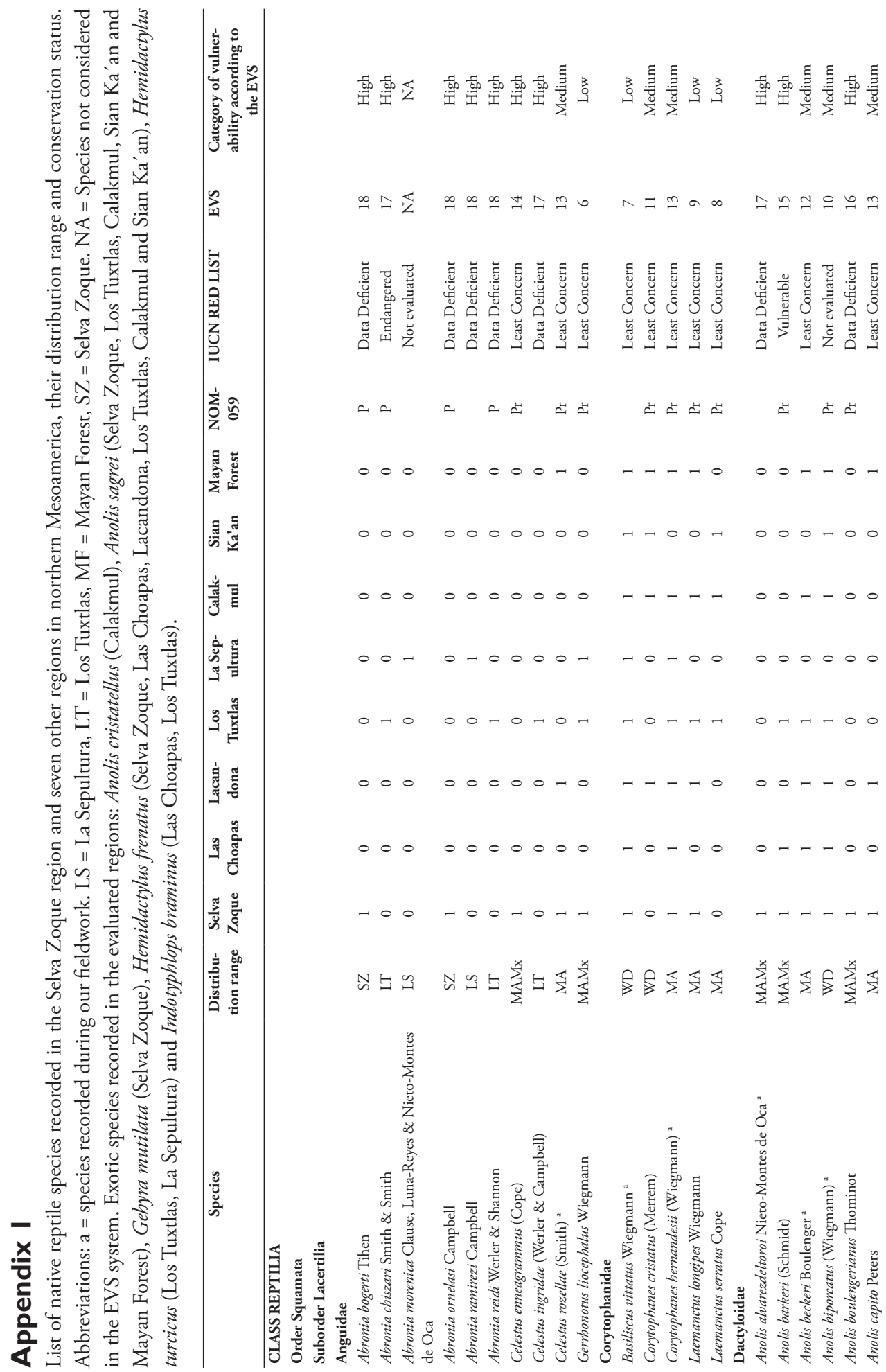




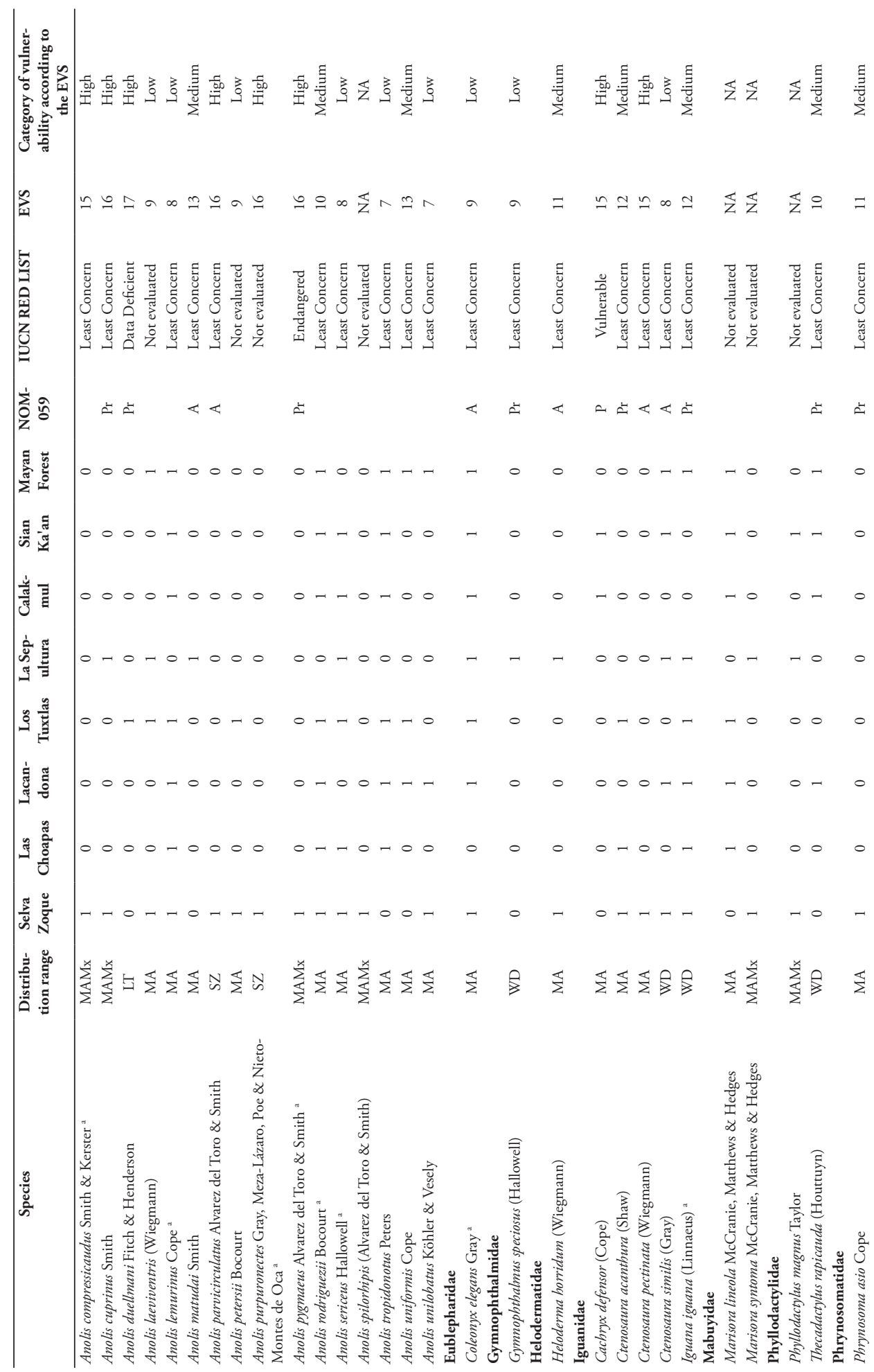




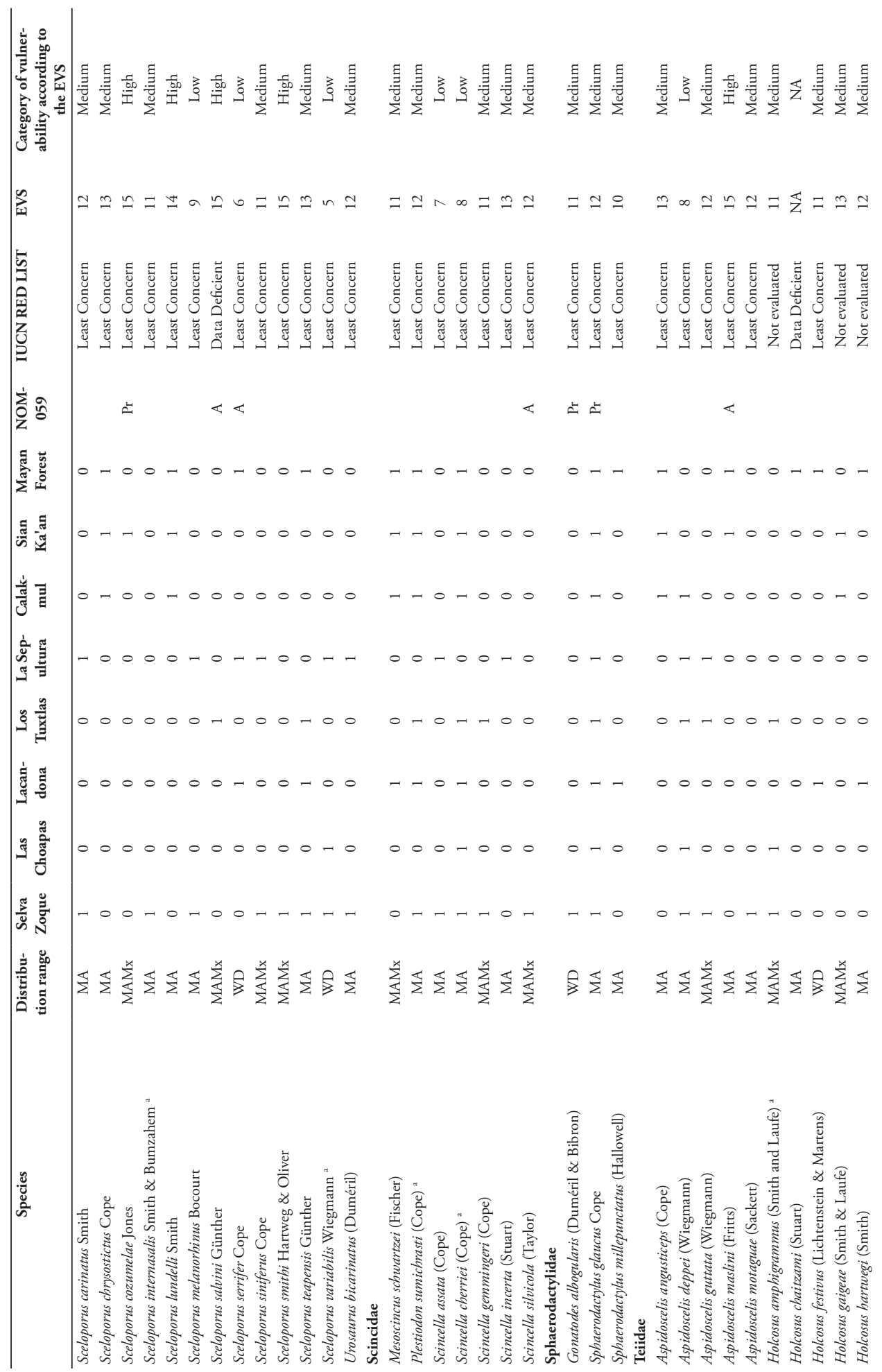




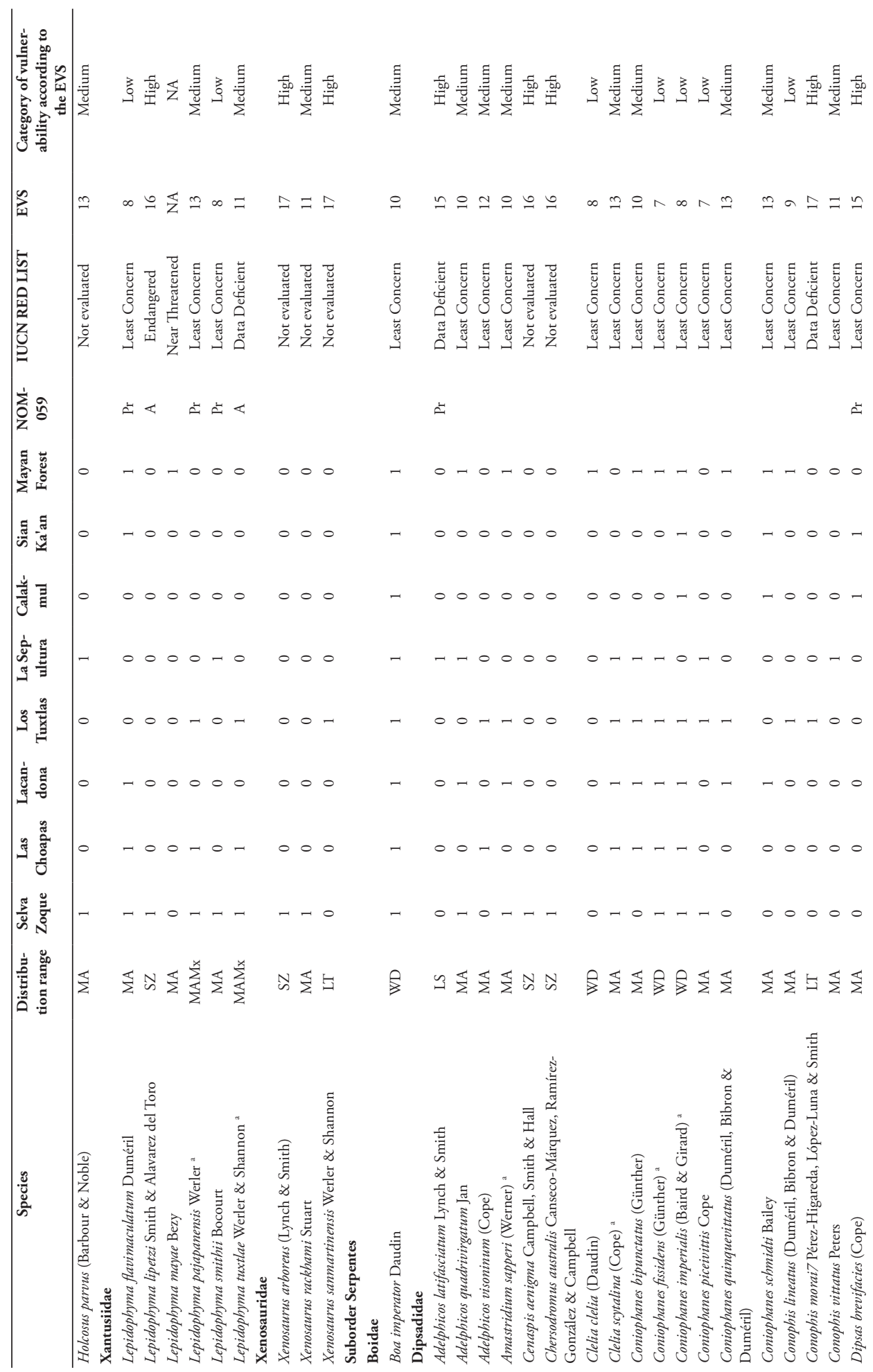




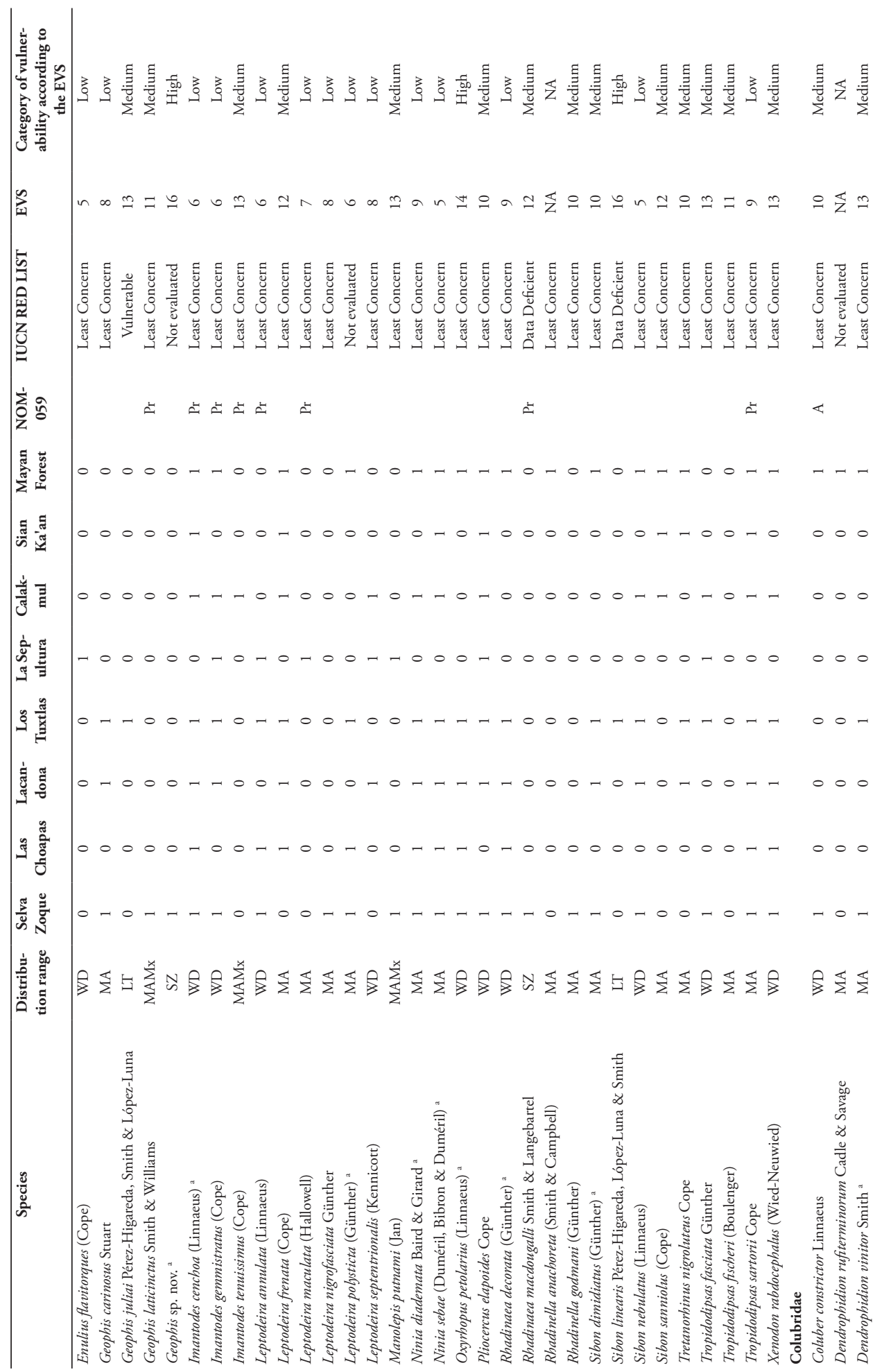




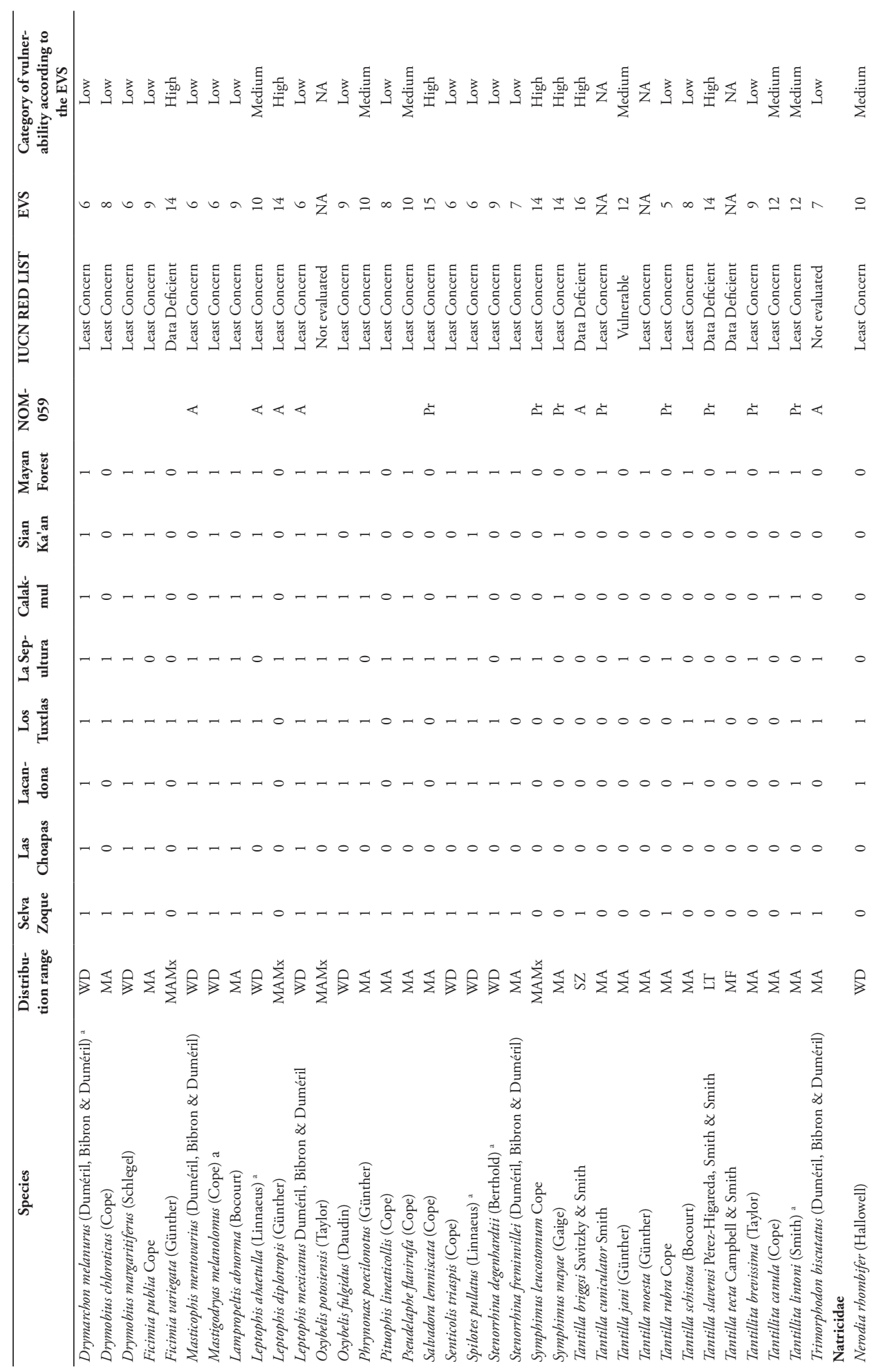




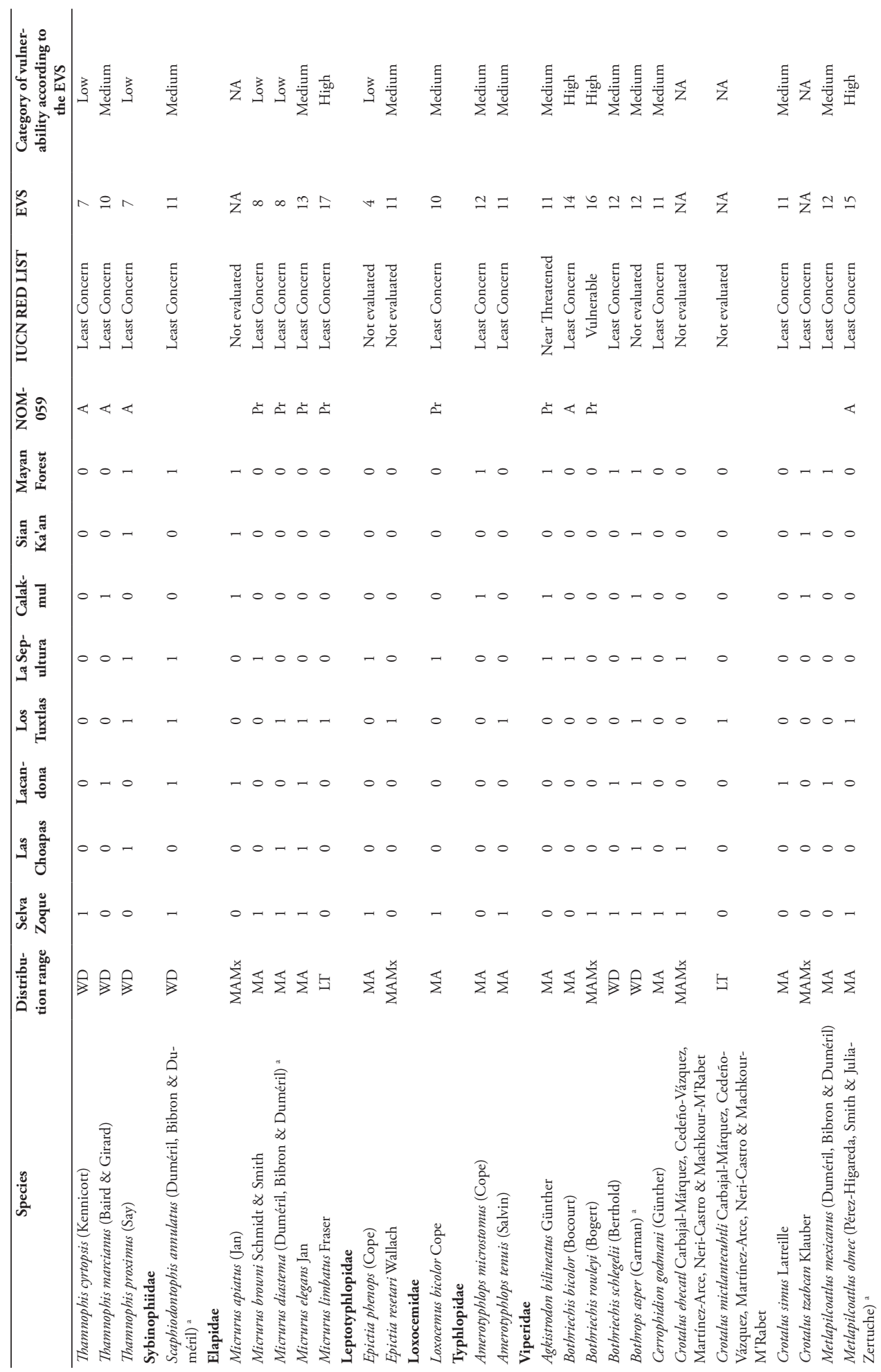




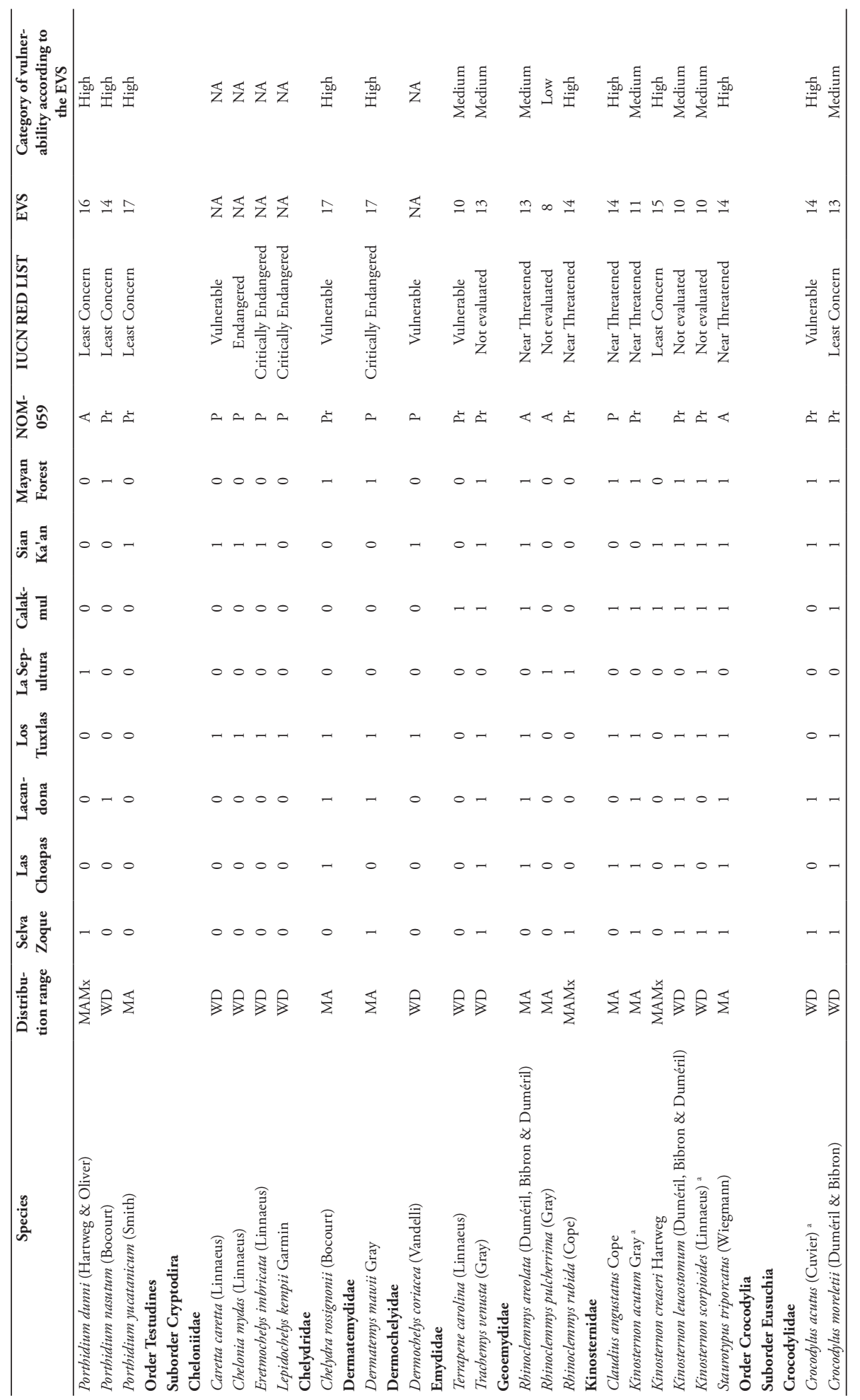

